\title{
The Ilha Anchieta Quartz Monzonite: the southernmost expression of ca. 500 Ma post-collisional magmatism in the Ribeira Belt
}

\author{
JOSÉ M. AZEVEDO SOBRINHO ${ }^{1}$, VALDECIR A. JANASI ${ }^{2}$, ANTONIO SIMONETTI ${ }^{3,4}$, \\ LARRY M. HEAMAN ${ }^{3}$, JAIR SANTORO ${ }^{1}$ and HÉLIO N. DINIZ ${ }^{1}$ \\ ${ }^{1}$ Instituto Geológico, Secretaria do Meio Ambiente do Estado de São Paulo, \\ Avenida Miguel Stefano, 3900, 04301-903 São Paulo, SP, Brasil \\ ${ }^{2}$ Departamento de Mineralogia e Geotectônica, Instituto de Geociências, \\ Universidade de São Paulo/USP, Rua do Lago 652, 05508-080 São Paulo, SP, Brasil \\ ${ }^{3}$ Department of Earth and Atmospheric Sciences, University of Alberta, \\ 1-26 Earth Sciences Building, Edmonton, Alberta, Canada T6G 2E3 \\ ${ }^{4}$ Currently at Department of Civil Engineering \& Geological Sciences, \\ 156 Fitzpatrick Hall, University of Notre Dame, Notre Dame, IN 46556, USA \\ Manuscript received on September 9, 2009; accepted for publication on December 15, 2010
}

\begin{abstract}
The Ilha Anchieta Quartz Monzonite (IAQM) occupies most of the homonymous island in the coast of the state of São Paulo, and is intrusive into foliated rocks of the $\sim 565 \mathrm{Ma}$ Ubatuba Charnockite. The main petrographic variety is a porphyritic biotite-hornblende quartz monzonite with 2-4 cm tabular microcline megacrysts set in a medium-grained groundmass and magmatic foliation. Outcrop-scale structures indicate cumulative processes (modal and grain-size magmatic banding) and interaction with basic magmas (mafic microgranular enclaves). Lithogeochemical data indicates that the main variety is intermediate to acid $\left(\mathrm{SiO}_{2}=63-67 \%\right)$, alkali-calcic, metaluminous and magnesian $(\mathbf{m g \# ~} \sim 30)$, showing moderate $\mathrm{Sr}(300-400 \mathrm{ppm})$ and $\mathrm{Ba}(\sim 1500 \mathrm{ppm})$ contents and relatively high $\mathrm{HFSE}(\mathrm{Nb}=40 \mathrm{ppm} ; \mathrm{Zr}=$

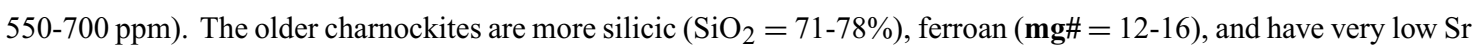
(13-80 ppm) contents, resulting in $\mathrm{Ba} / \mathrm{Sr}$ ratios remarkably higher than the IAQM (10 versus 4). LA-MC-ICPMS U-Pb zircon dating of the IAQM yielded $499.7 \pm 5.9 \mathrm{Ma}$. This is the youngest magmatic age identified so far in the crystalline basement of the state of São Paulo, and indicates that the pluton is the southernmost expression of the post-collisional "G5" magmatism in the Ribeira Belt.
\end{abstract}

Key words: granite, lithogeochemistry, LA-ICPMS, zircon U-Pb dating, Ribeira Belt.

\section{INTRODUCTION}

Granitic rocks are major constituents of the coastal areas of southeast Brazil, but most occurrences are known only at a reconnaissance scale, which is in part attributable to the difficulty of mapping due to dense vegetation and mountainous terrain. Lack of detailed work is particularly true in the northern shoreline of the state of São Paulo, where even excellent rock exposures near popular beaches have not yet attracted the atten-

Correspondence to: Valdecir de Assis Janasi

E-mail: vajanasi@usp.br tion of geologists. As a result, this region, formed by high-metamorphic grade rocks and several granite bodies, including the Ubatuba Charnockite (Gasparini and Mantovani 1979), remains as one of the least studied portions of the Neoproterozoic Ribeira Belt.

Regional correlations indicate that the geology of the northern shoreline of São Paulo is an extension to the SSW of the Neoproterozoic Oriental Terrane (Heilbron et al. 2008), thought to represent a magmatic arc setting. The Rio Negro Magmatic Arc (Tupinambá et al. 2000) is thought to have evolved by eastward-directed subduc- 
tion of the São Francisco paleoplate until 635-620 Ma and was accreted to it at ca. 580-550 Ma, a time interval when large amounts of "syn-collisional" granites were generated (Campos Neto and Figueiredo 1995, Silva et al. 2005, Heilbron et al. 2008).

Few precise magmatic ages were obtained in rocks from Oriental Terrane in the state São Paulo, and none fall in the range thought to correspond to subductionrelated magmatism in the Rio Negro Arc. ID-TIMS monazite ages obtained in migmatites and in a muscovite-biotite granite from the Natividade da Serra batholith (Janasi et al. 2003 and unpublished data) are similar at $\sim 590 \mathrm{Ma}$, and would probably correspond to early stages of the "syn-collisional" period. The IDTIMS zircon age of the Ubatuba Charnockite ( $\sim 565 \mathrm{Ma})$ is the youngest magmatic age obtained so far in a granite from this region. This age still falls within the "syncollisional" range defined in Rio de Janeiro (Heilbron et al. 2008) and is the same as that of enderbites intruding the Rio Negro Magmatic Arc ("early post-collisional phase of enderbite magmatism" of Campos et al. 2004). An important difference, however, is the "within-plate" geochemical signature of the Ubatuba charnockites (Gasparini and Mantovani 1979).

Geological mapping of the Ilha Anchieta recently completed for the Secretaria do Meio Ambiente do Estado de São Paulo (J.M. Azevedo Sobrinho et al. 2004, unpublished report) has shown that most of the island is constituted by a quartz monzonite pluton intrusive into the Ubatuba Charnockite, unraveling the latest events of granite generation within the Oriental Terrane in São Paulo. This paper presents the geology, petrography, whole-rock chemistry and LA-MC-ICPMS U-Pb zircon dating of the Ilha Anchieta Quartz Monzonite. Our results demonstrate that this pluton can be correlated with the youngest event of granite generation reported in the Ribeira Belt further north ("G5" granites of PedrosaSoares et al. 2001, Wiedemann et al. 2002, dated around 515-480 Ma), which therefore extended over a broader region, reaching the southern region of São Paulo.

\section{GEOLOGICAL SETTING}

The Neoproterozoic Ribeira Belt in southeast Brazil is an orogenic belt developed along the SE border of the São Francisco craton during the convergence with an- other plate/microplate located to the east (Brito Neves et al. 1999, Heilbron and Machado 2003). Tectonic models for the evolution of the central part of the Ribeira Belt (state of Rio de Janeiro) propose east-vergent subduction of the São Francisco paleoplate, forming the Rio Negro Magmatic Arc in the Oriental Terrane that was eventually accreted to the São Francisco continent through a frontal collision that would have lasted from 590 to $550 \mathrm{Ma}$ (Heilbron and Machado 2003). This was followed by the accretion of the Cabo Frio Terrane in a new collisional or docking event at $535-510 \mathrm{Ma}$ (Schmitt et al. 2004) and finally by orogen collapse at 510-480 Ma.

In the south of this area in the of state of São Paulo, the accretion of the Ribeira Belt occurred through oblique strike-slip convergence to a NW-trending belt formed by the previous ( $\sim 630-610 \mathrm{Ma})$ collision between the São Francisco and Paranapanema cratons (Brito Neves et al. 1999, Campos Neto 2000). Two main geologic domains constitute the Ribeira Belt in São Paulo, from west to east: (1) the Embu Domain, dominated by mediumgrade metasupracrustal rocks of uncertain age $(<1.0 \mathrm{Ga}$ ? Alves 2009) metamorphosed at $\sim 800 \mathrm{Ma}$ and followed by different episodes of crust-derived granite magmatism, the most voluminous at 600-580 Ma (Janasi et al. 2003), and (2) the Coastal Domain, largely composed of orthogneisses and granitic rocks, with smaller exposures of high-grade migmatites, in part of supracrustal derivation. Rocks from the Coastal Domain show relatively young $\mathrm{Sm}-\mathrm{Nd} \mathrm{T}$ (DM) (often $<1.5 \mathrm{Ga}$, compared to $\sim 2.0$ Ga or older in the Embu Domain); the high-grade metamorphism peaked at $\sim 590 \mathrm{Ma}$. This last age coincides with the few dated "syn-orogenic" granites (e.g., Natividade da Serra, dominated by muscovite-biotite granite; Janasi et al. 2003). The Ubatuba Charnockite is younger, as shown by unpublished ID-TIMS zircon dating ( $\sim 565$ Ma; C. Tassinari, personal communication), and consists of a quartz mangerite-charnockite-granite association with coeval dioritic bodies; the rocks are commonly affected by solid-state foliation, but show a within-plate geochemical signature (Gasparini and Mantovani 1979, R. Neumann, Unpublished Master Dissertation, Universidade de São Paulo 1993). Still younger granitic plutons, although suspected from the less deformed character of some occurrences (e.g., Guarujá Granite, Dias 
Neto et al. 2008, Santos Granite, A.T.S.F. Silva et al. 1977, unpublished report), were not studied in detail or dated so far.

The last magmatic manifestations in this region are Cretaceous tholeiitic and alkaline dike swarms and stocks of syenite-gabbro association related to continent rifting and subsequent opening of the South Atlantic.

\section{LOCAL GEOLOGY}

\section{Geological Map of Ilha Anchieta}

The geological map of Ilha Anchieta is presented in Figure 1. The oldest rocks recognized in the island appear at its westernmost portion as a $\sim \mathrm{N}-\mathrm{S} 0-2 \mathrm{~km}$ wide strip of foliated charnockites and associated leucogranites from the Ubatuba Charnockite. The rest of the island is occupied by the younger Ilha Anchieta Quartz Monzonite (IAQM), whose intrusive character in relation to the charnockitic rocks has been observed in several outcrops along the island's western coast. It shows a magmatic foliation with average direction N-S dipping $55-85^{\circ} \mathrm{E}$; the foliation of both the IAQM and the older charnockites shows an inflection from NNE in the north to NNW in the south of the island, suggestive of an inward-dipping body that is round-shaped in plan view.

The charnockites are greenish rocks with low color index $(\mathrm{CI}=4-7)$ and syenogranitic composition (Table I; Fig. 2); a solid-state foliation is evidenced by the elongated shape of quartz and mafic minerals (Fig. 3a). In many localities, the charnockites are seen to gradually pass into pinkish granites; quartz-rich hololeucocratic granites with $\mathrm{CI} \sim 2$ may occur in association with the charnockites or predominate in many outcrops, but were not distinguished at the mapping scale.

The predominant rock type in the IAQM is a porphyritic biotite-hornblende quartz monzonite with $\mathrm{CI}=$ 10-15 and abundant tabular pinkish $\mathrm{K}$ feldspar megacrysts up to $2-4 \mathrm{~cm}$ long in a medium-grained groundmass (Fig. 3b). A flow foliation evidenced by the preferred alignment of $\mathrm{K}$ feldspar megacrysts is usually well developed. A border facies with slightly lower CI (8-12) is present in several portions close to the western contact with the enclosing charnockites; closely packed oriented tabular $\mathrm{K}$ feldspar megacrysts (on average $\sim 2 \mathrm{~cm}$ long) and a lesser proportion of matrix result in a "trachytoid" texture (Fig. 3c). Modal analyses of these two varieties (Table I; Fig. 3) indicate composi- tions close to the limit between the quartz monzonite and monzogranite fields (15-18\% quartz; 31-39\% plagioclase). More felsic granites $(\mathrm{CI}<5)$ occur as discrete meter-sized bodies of pink inequigranular syenogranite (cf. modal analysis of sample IA-10e in Table I) that intrude the predominant porphyritic quartz monzonite in several outcrops (Fig. 3d). Thin aplitic dikes are the last magmatic expressions of the IAQM.

Subvertical diabase dikes oriented N45-60E with thicknesses varying from $<1$ to $\sim 10 \mathrm{~m}$ appear in several localities of Ilha Anchieta, and are related to the Serra do Mar Dike Swarm of the Cretaceous ( 140-134 Ma) Paraná-Etendeka Large Igneous Province (Valente et al. 2007). An interesting feature associated with one of these tholeiitic dikes crops out at the western portion of Ilha Anchieta: a magmatic breccia produced by the interaction between the basaltic magma and the enclosing foliated charnockites/granites. The breccia is exposed over an area of tens of meters, and is constituted of dm-sized subangular blocks of charnockite/granite in a "hybrid" rock matrix ("spotted" quartz diorite); petrographic evidences indicate that smaller granite fragments enclosed in the diabase were partially to totally melted (J.M. Azevedo Sobrinho et al. 2004, unpublished results). Some of the mafic dikes present in the island may be related to the $\sim 85 \mathrm{Ma}$ alkaline magmatism, which generated several of the dikes exposed onshore (Garda 1996), but this could not be confirmed in this study.

\section{OUTCROP-SCALE STRUCTURES IN THE IAQM}

The border IAQM trachytoid facies exhibits near the contact with the enclosing charnockites abundant centimeter- to meter-sized xenoliths of these rocks (Fig. 4a). In one locality (Fig. 4b) the IAQM gets progressively darker and finer-grained over $\sim 1 \mathrm{~m}$ towards the contact with the charnockite.

Mafic microgranular enclaves with elliptical shape are fairly common in the porphyritic granite. They are mostly centimeter-sized and show evidence of plasticstate interaction with the host granite, such as molding around megacrysts. $\mathrm{K}$ feldspar xenocrysts with sizes varying from identical to smaller than those of the host granite are common; hornblende-mantled quartz xenocrysts are less abundant, though remarkably developed when present (Fig. 4c). 


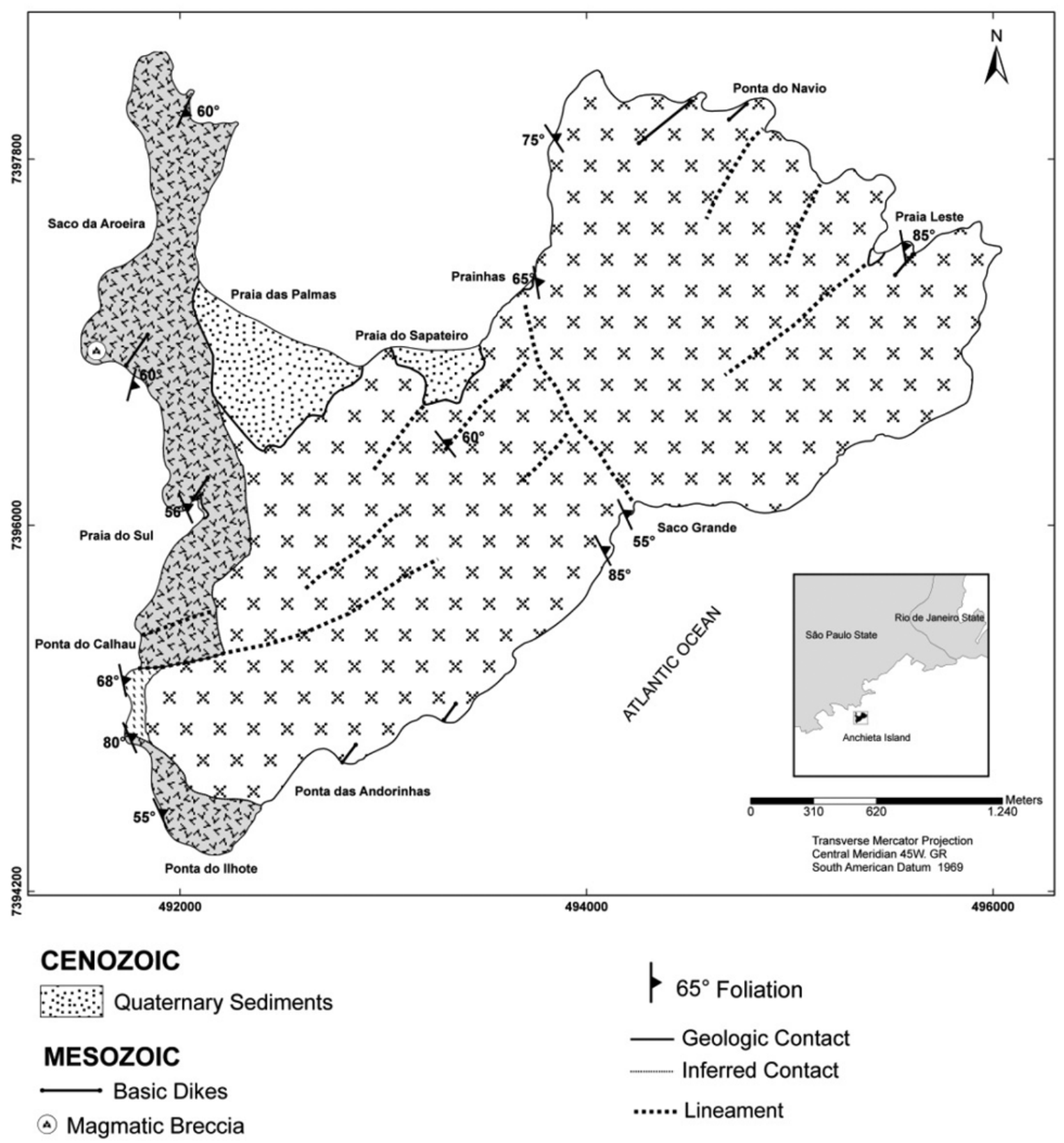

\section{MEDIUM TO UPPER CAMBRIAN ( $500 \mathrm{Ma})$}

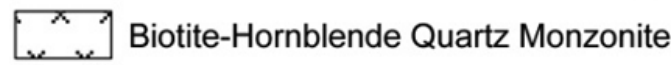

灌㳘温 Trachytoid Quartz Monzonite

NEOPROTEROZOIC ( $\sim 565 \mathrm{Ma})$

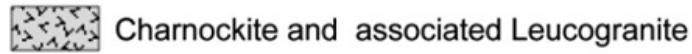

Fig. 1 - Geological map of Ilha Anchieta. 
500 Ma ILHA ANCHIETA QUARTZ MONZONITE, RIBEIRA BELT

TABLE I

Modal analyses data of IAQM and enclosing charnockitic-granitic rocks.

\begin{tabular}{l|c|c|c|c|c|c|c|c|c}
\hline \multicolumn{1}{c}{ Rock type } & p-QM & p-QM & t-QM & t-QM & inq-G & chk & chk & chk & lg \\
\hline \multicolumn{1}{c}{ Sample / } & IA10c & IA33b & IA15 & IA34a & IA10e & IA20a & IA24 & IA11 & IA20 \\
Mineral (\%) & & & & & & & & & \\
\hline Quartz & 16.8 & 14.9 & 18.2 & 14.6 & 30.6 & 23.6 & 27.2 & 26.4 & 47.5 \\
Plagioclase & 35.7 & 31.4 & 38.7 & 32.6 & 19.8 & 21.0 & 21.4 & 20.0 & 17.8 \\
K feldspar & 31.0 & 42.1 & 31.8 & 44.0 & 45.6 & 51.4 & 44.6 & 49.8 & 32.5 \\
Hornblende & 7.2 & 8.7 & 4.9 & 3.4 & 1.4 & 2.8 & 1.8 & 2.2 & $\operatorname{Tr}$ \\
Biotite & 6.8 & 1.4 & 4.9 & 4.0 & 1.8 & 1.6 & 3.4 & 0.8 & 1.9 \\
Orthopyroxene & - & - & - & - & - & - & 0.8 & - & - \\
Fe-Ti oxide & 1.7 & 1.1 & 1.5 & 1.2 & 0.4 & $\operatorname{Tr}$ & 0.6 & 0.6 & 0.1 \\
Apatite & $\operatorname{Tr}$ & 0.4 & $\operatorname{Tr}$ & 0.2 & 0.2 & $\operatorname{Tr}$ & $\operatorname{Tr}$ & $\operatorname{Tr}$ & $\operatorname{Tr}$ \\
Zircon & 0.2 & $\operatorname{Tr}$ & $\operatorname{Tr}$ & $\operatorname{Tr}$ & 0.2 & $\operatorname{Tr}$ & $\operatorname{Tr}$ & $\operatorname{Tr}$ & $\operatorname{Tr}$ \\
Titanite & $\operatorname{Tr}$ & - & $\operatorname{Tr}$ & - & $\operatorname{Tr}$ & - & - & - & - \\
Allanite & 0.2 & - & - & - & $\operatorname{Tr}$ & - & 0.2 & 0.2 & 0.2 \\
Sericite & $\operatorname{Tr}$ & $\operatorname{Tr}$ & $\operatorname{Tr}$ & $\operatorname{Tr}$ & $\operatorname{Tr}$ & - & - & $\operatorname{Tr}$ & $\operatorname{Tr}$ \\
Carbonate & 0.5 & $\operatorname{Tr}$ & - & - & - & - & - & - & - \\
Q & 20.1 & 16.9 & 20.5 & 16.0 & 31.9 & 24.6 & 29.2 & 27.4 & 48.6 \\
A & 37.1 & 47.6 & 35.9 & 48.2 & 47.5 & 58.5 & 47.9 & 51.8 & 33.2 \\
P & 42.8 & 35.5 & 43.6 & 35.8 & 20.6 & 21.9 & 22.9 & 20.8 & 18.2 \\
M & 16.1 & 11.6 & 11.3 & 8.8 & 4.0 & 4.4 & 6.8 & 3.8 & 2.2 \\
\hline
\end{tabular}

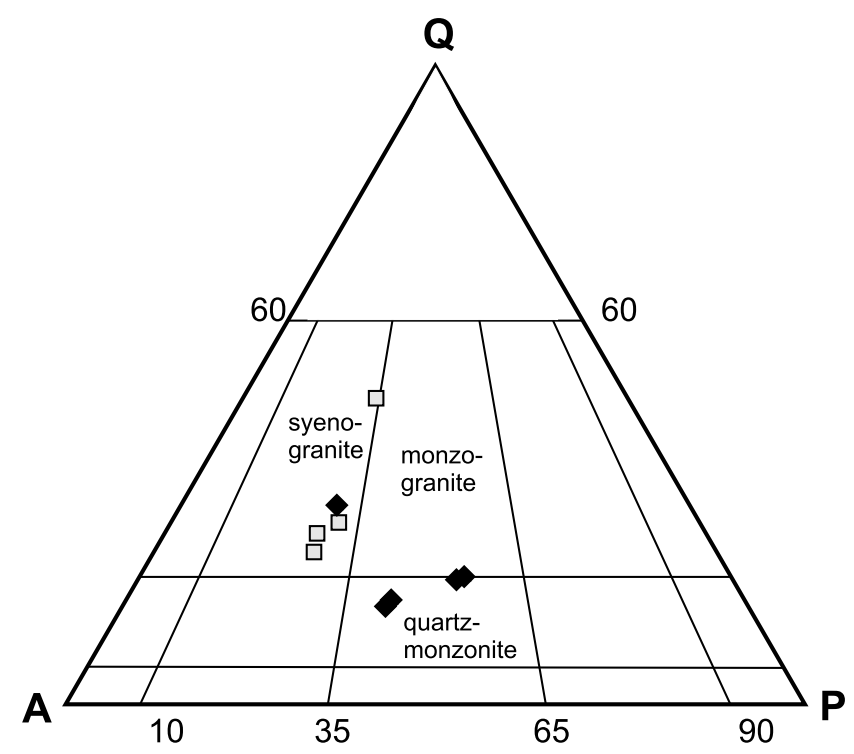

Fig. 2-QAP diagram (Streckeisen 1976) with results of modal analyses of IAQM and enclosing charnockitic-granitic rocks. Orhopyroxene-bearing syeno- and monzogranites are classified as charnockites.

Magmatic layering is locally conspicuous and may indicate that cumulative processes were important in the formation of the porphyritic IAQM. The best exposures of these features were found in outcrop IA-10 (Saco Grande locality), where modal and grain-size layering parallel to the steep-dipping magmatic foliation is ob- served. Most commonly, the layering begins with medium-grained equigranular mafic-rich centimeter-sized layers that are in sharp contact with the underlying "normal" porphyritic quartz monzonite and gradually pass into lighter felsic rocks (Fig. 4d); this sequence is repeated cyclically for a few meters. One possible inter- 

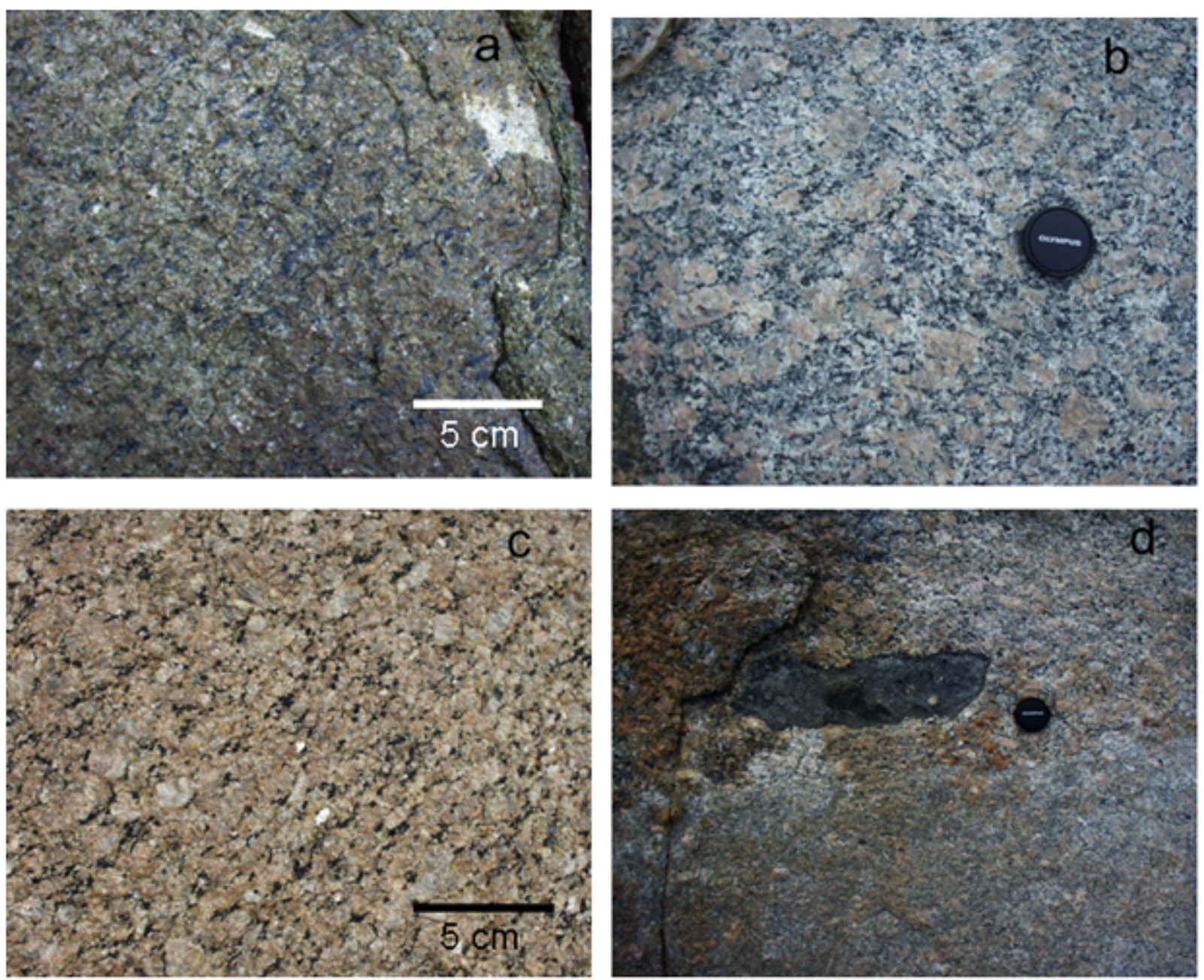

Fig. 3 - Field images of the main granite rock varieties found in Ilha Anchieta. (a) foliated charnockite; (b) porphyritic quartz monzonite; (c) trachytoid quartz monzonite (note the lower mafic content and a more evident flow foliation); (d) inequigranular granite with an elliptical dark enclave.

pretation for such structures is that they developed at the bottom of a magma chamber over a nearly horizontal substrate; in this case, their attitude would be an evidence that the pluton was subject to eastward tilting, and the fault affecting layering in Fig. $4 \mathrm{~d}$ would be originally of normal character.

\section{PETROGRAPHY}

The Ubatuba Charnockite: Foliated Charnockite AND LEUCOGRANITE

The charnockites are typically medium-grained, leucocratic $(\mathrm{CI}<7)$, inequigranular rocks of syenogranitic composition showing visible effects of solid-state deformation. Part of the fine-grained groundmass material has a granoblastic texture and is a product of recrystallization. The main minerals are, in order of abundance, K-feldspar, quartz, oligoclase, reddish-brown biotite, hornblende and orthopyroxene. Accessory minerals are Fe-Ti oxides, apatite, zircon and allanite.

Quartz as elongated xenomorphic grains defines the rock foliation, and may show undulous extinction. $\mathrm{K}$-feldspar, also as elongated crystals with irregular to round borders, shows string perthite and is devoid of chessboard twinning. Plagioclase of oligoclase to andesine composition shows, in some cases, anti-perthitic intergrowths and may appear as myrmekite along the $\mathrm{K}$ feldspar borders.

Orthopyroxene is xenomorphic and in part altered to greenish phyllosilicate masses along fractures and 

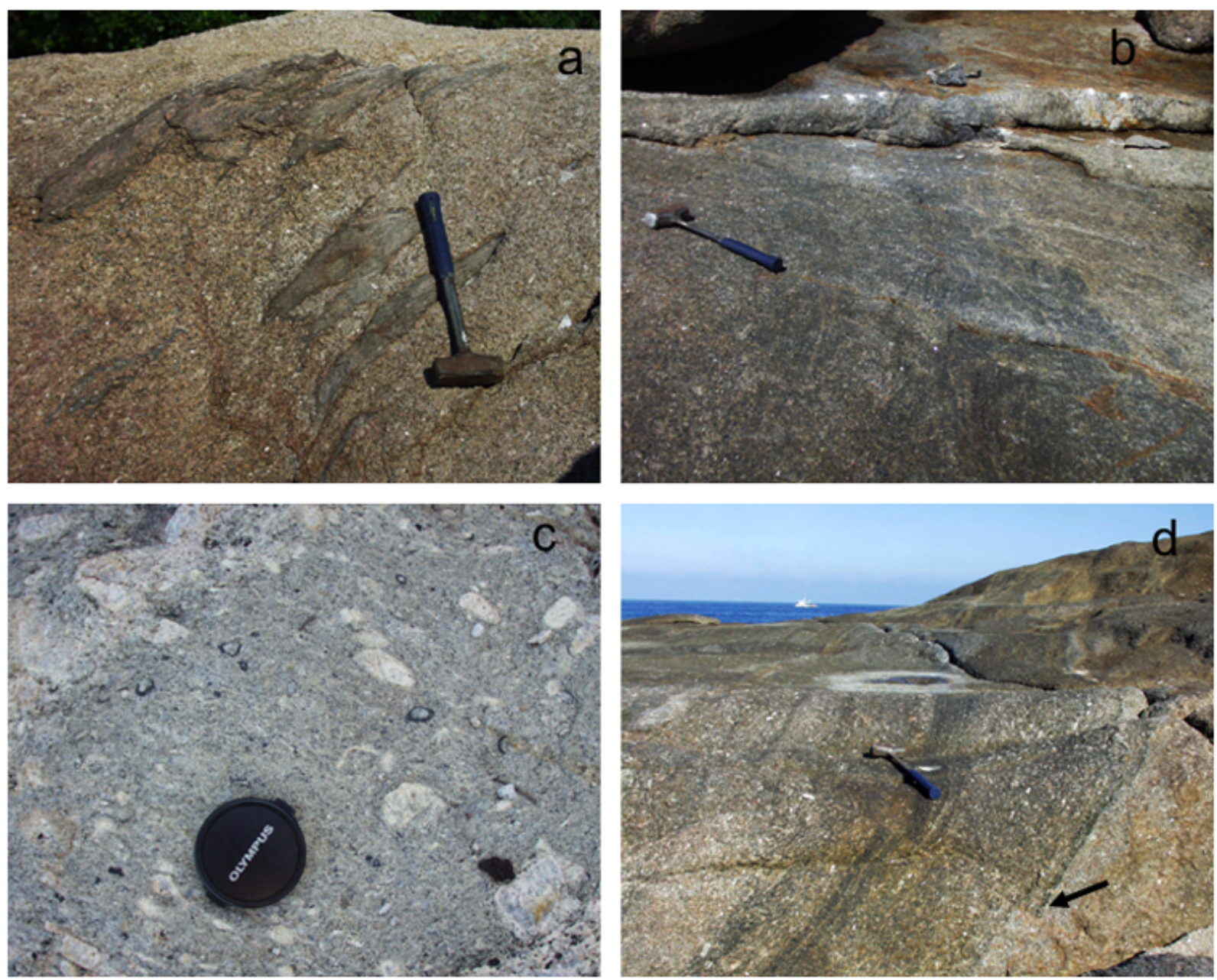

Fig. 4 - Field images of some outcrop-scale structures in the IAQM. (a) xenoliths of foliated charnockite in trachytoid quartz monzonite near the contact; (b) detail of the contact between trachytoid quartz monzonite (left) and charnockite; to the right of the hammer, the quartz monzonite turns progressively darker; charnockite corresponds to the lighter portion at the extreme right of the photograph; (c) detail of a dark microgranular enclave with hornblende + biotite-mantled quartz and microcline xenocrysts; (d) quartz monzonite showing modal and grain-size magmatic banding moderately east-dipping; note a $\sim 10 \mathrm{~cm}$ displacement of layering by a brittle fault (indicated by an arrow).

cleavages. Hornblende and biotite are commonly associated with the pyroxene; when secondary, biotite shows symplectitic intergrowths with quartz.

The foliated leucogranites differ from the texturally similar charnockites to which they are often associated by the pink color, lower $\mathrm{CI}(<4)$, lack of orthopyroxene, and higher abundance of quartz, which may reach up to $40 \%$ in volume.

\section{The IlHa Anchieta Quartz Monzonite}

The predominant rock type in the IAQM is a porphyritic biotite-hornblende quartz monzonite with $\mathrm{CI} \sim 15-10$. The porphyritic texture is defined by tabular to oval- shaped microcline megacrysts in part aligned by magmatic flow set in a medium to coarse-grained matrix. Microcline, often with vein or patch perthite, may show chessboard twining; it always has a "dirty" aspect due to alteration to clay minerals. Plagioclase (oligoclaseandesine) is xenomorphic to subidiomorphic, and may be slightly to moderately replaced by sericite or, less often, saussuritized. Myrmekite is common at the contacts with microcline. Quartz is xenomorphic, and may show undulose extinction.

The mafic minerals, reddish-brown biotite and green hornblende, usually occur in association, and do not show any evident orientation. The accessory min- 
erals (zircon, titanite, apatite, allanite and Fe-Ti oxides) tend to occur in association forming mafic aggregates. Hornblende may be partly replaced by greenish biotite and/or actinolite; as part of these reactions, some opaque minerals and titanite form along cleavages or fractures or occur as coronas around the original crystals. Greenish biotite may also replace the original dark biotite, and shows opaque minerals along its cleavage.

The more felsic granites $(\mathrm{CI}<7)$ intrusive into the porphyritic biotite-hornblende quartz monzonite are texturally distinct. They show a seriated inequigranular texture with scattered up to $1.5 \mathrm{~cm}$ long microcline phenocrysts set in a fine- to medium-grained matrix. Mafic and accessory minerals are the same as in the porphyritic granites, though in lower proportion. Sericite-muscovite may occur partly replacing the feldspars or biotite. Fe-Ti oxides are in part mantled by titanite.

Aplitic dikes with saccaroidal texture and very low CI $(<3)$ still show the same mafic mineralogy of the granites, with brownish biotite and traces of hornblende as very small crystals dispersed in the rock. Plagioclase is strongly sericitized, and albite rims occur along the contacts of plagioclase and microcline.

\section{GEOCHRONOLOGY: LA-MC-ICPMS DETERMINATIONS IN ZIRCON}

\section{PROCEDURES}

Field relationship indicates that the IAQM intrudes the Ubatuba Charnockite, which was up to now the youngest granitic rock dated in the coastal area of São Paulo. Zircon crystals were extracted from sample IA-10d using standard mineral separation procedures including rock milling, heavy mineral concentration using a Wiffley Table, heavy liquids and a Frantz Isodynamic Separator at the Instituto de Geociências, Universidade de São Paulo.

About 80 clean zircon crystals, mostly free of fractures and inclusions, were handpicked and mounted in a 1 inch-wide cylindrical epoxy mount. Backscattered images of all crystals were obtained in order to investigate internal structures and to help selecting the best areas for laser incidence. LA-MC-ICPMS analyses were performed at the Radiogenic Isotope Facility, University of Alberta, Canada. Data were acquired using a NuPlasma MC-ICP-MS (Nu Instruments, UK) coupled to a UP213 laser ablation system (New Wave Research, USA); the MC-ICP-MS instrument is equipped with 12
Faraday cups and three discrete-dynode secondary electron multipliers (Simonetti et al. 2005, 2008). Ablated particles are transported with a He carrier gas and mixed with nebulized thallium (via a DSN-100 dessolvating nebulizing system) prior to entering the plasma. Correction for laser induced elemental fractionation (LIEF) was achieved by concurrent analysis of the international SHRIMP zircon standard BR266 (Stern and Amelin 2003). The measured $\mathrm{Pb} / \mathrm{U}$ values for the standard are compared to the 'accepted' values (obtained by IDTIMS), and normalization factors are determined using a 'standard-sample bracketing' technique. The measured ${ }^{205} \mathrm{Tl} /{ }^{203} \mathrm{Tl}$ ratio from the nebulized $\mathrm{Tl}$ solution $\left(\sim 1 \mathrm{ppb}\right.$ in $\left.2 \% \mathrm{HNO}_{3}\right)$ is used to correct the measured $\mathrm{Pb}$ isotope ratios for instrumental mass bias. The analytical protocol adopted here yields $2 \sigma$ relative standard deviations that are between 0.3 to $1 \%\left({ }^{207} \mathrm{~Pb} /{ }^{206} \mathrm{~Pb}\right)$ and 1 to $3 \%\left({ }^{206} \mathrm{~Pb} /{ }^{238} \mathrm{U}\right.$ and $\left.{ }^{207} \mathrm{~Pb} /{ }^{235} \mathrm{U}\right)$. Details of the in-situ dating technique are described in Simonetti et al. $(2005,2008)$.

\section{RESULTS}

A total of thirty-five $40 \mu \mathrm{m}$-wide laser spots were performed in sample IA-10d; results are presented in Table II and Figure 5. Most analyses are nearly concordant; the weighed mean ${ }^{207} \mathrm{~Pb} /{ }^{206} \mathrm{~Pb}$ age obtained for 22 spots with $<7 \%$ discordance is $499.7 \pm 5.9 \mathrm{Ma}(2 \sigma$; MSWD $=1.0$ ), considered as the best estimate of the crystallization age of the Ilha Anchieta Quartz Monzonite. The weighed mean ${ }^{238} \mathrm{U} /{ }^{206} \mathrm{~Pb}$ age of the same 22 spots yields 510.3 \pm 7.0 Ma and a higher MSWD (3.0).

A few analyses show evidence of inheritance with slightly older age; in particular, points $18 \mathrm{~B}$ and $\mathrm{C}$ are concordant at $\sim 540 \mathrm{Ma}$, and point $20-2$ is concordant at $593 \pm 18 \mathrm{Ma}$. The analyses indicating the presence of zircon inheritance and/or those that display significant discordance ( $>8 \%$ ) were not used in the age calculations.

\section{DISCUSSION}

The age around $500 \mathrm{Ma}$ obtained for the Ilha Anchieta Quartz Monzonite in this study is remarkable within the regional geological framework since it is the youngest magmatic age reported so far in the crystalline basement of the state of São Paulo. The Coastal Domain in São Paulo is recognized as younger compared to terranes 


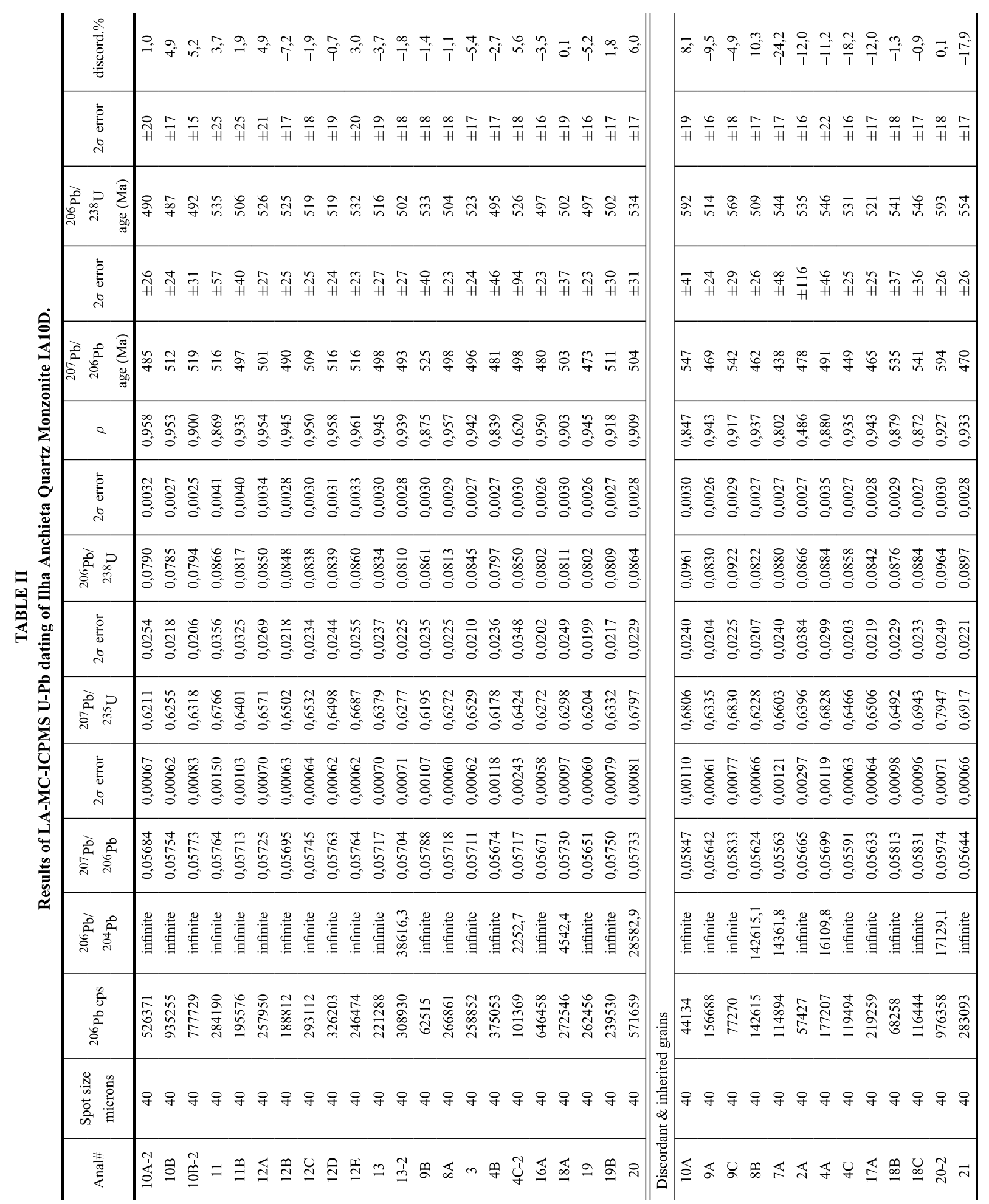




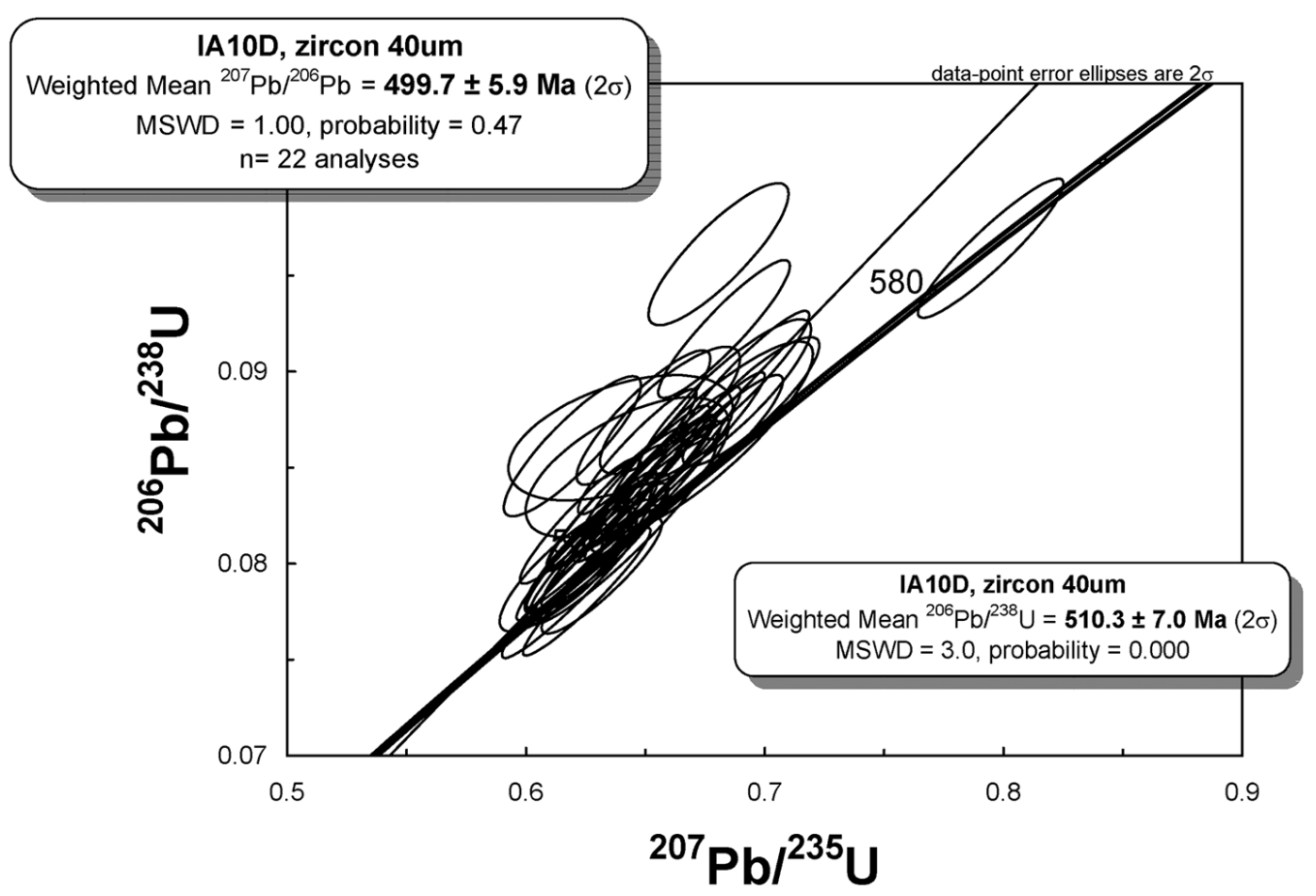

Fig. 5 - U-Pb Concordia diagram showing the results of LA-MC-ICPMS dating of zircon crystals from sample IA-10d.

located inland within the Ribeira Belt; syn-orogenic granites are typically $\sim 590 \mathrm{Ma}$ (e.g., Janasi et al. 2003), and the youngest intrusion investigated prior to this study is the Ubatuba Charnockite, with a U-Pb ID-TIMS zircon age of $\sim 565 \mathrm{Ma}$. In spite of its "within-plate" geochemical signature, the Ubatuba Charnockite is thoroughly affected by a solid-state foliation and based on field relationships is older than the Ilha Anchieta Quartz Monzonite.

The new U-Pb zircon age reported here for the Ilha Anchieta Quartz Monzonite provides evidence that it is the southernmost occurrence of magmatism related to the $\sim 510-480$ Ma belt of "I-type" K-rich granites and associated mafic rocks ("G-5") known to extend from latitude $16^{\circ} \mathrm{S}$ in the state of Bahia to $22^{\circ} \mathrm{S}$ in south Rio de Janeiro (Pedrosa-Soares et al. 2001, Wiedemann et al. 2002).

\section{GEOCHEMISTRY}

Nine samples representative of the main petrographic varieties of the IAQM and enclosing charnockite-leucogranite suite were analyzed for major and trace elements by XRF at the Instituto de Geociências, Universidade de São Paulo, according to the procedures described by Mori et al. (1999).

Our preliminary results indicate that the IAQM has a restricted compositional range with intermediate $\mathrm{SiO}_{2}$ contents (63-67 wt\%), whereas the enclosing charnockite-leucogranite rocks (CHLG) are richer in $\mathrm{SiO}_{2}$ (71-78\%) (Table III). The IAQM is metaluminous (A/ $\mathrm{CNK}=0.85-0.92)$, alkali-calcic and magnesian ( $\mathbf{m g \#}$ $\sim 30)$; this contrasts with the ferroan $(\mathbf{m g \#}=12-16)$ metaluminous to slightly peraluminous $(\mathrm{A} / \mathrm{CNK}=0.94$ 1.03) character of the CHLG (Fig. 6; fields of Frost et al. 2001).

Variation diagrams using $\mathrm{SiO}_{2}$ as the differentiation index are presented in Figures 7 and 8; for comparison, trends of the main Ubatuba Charnockite Batholith (UCB) (R. Neumann, unpublished data, Master Dissertation, Universidade de São Paulo, 1993) are also shown. It can be observed that the CHLG samples perfectly fit along the UCB trend, which is continuous between 65 and $78 \mathrm{wt} \% \mathrm{SiO}_{2}$, corresponding to its more differentiated compositions. Compared to the UCB trend, the IAQM is clearly richer in $\mathrm{MgO}, \mathrm{TiO}_{2}, \mathrm{P}_{2} \mathrm{O}_{5}$ and $\mathrm{Sr}$, and has much lower $\mathrm{Ba} / \mathrm{Sr}$ (4-5 versus $\sim 10$ in typical CHLG samples, which show remarkably low $\mathrm{Sr}$ con- 
TABLE III

Results of chemical analysis of granitic and charnockitic rocks from Anchieta Island.

\begin{tabular}{|c|c|c|c|c|c|c|c|c|c|}
\hline & \multicolumn{4}{|c|}{ Ilha Anchieta Granite } & & \multicolumn{4}{|c|}{ Charnockite-leucogranite suite } \\
\hline & $\begin{array}{c}\text { IA-33B } \\
\text { p-QM }\end{array}$ & $\begin{array}{c}\text { IA-10C } \\
\text { p-QM }\end{array}$ & $\begin{array}{c}\text { IA-34A } \\
\text { tr-QM }\end{array}$ & $\begin{array}{l}\text { IA-15 } \\
\text { tr-QM }\end{array}$ & $\begin{array}{l}\text { IA-10E } \\
\text { ineq-G }\end{array}$ & $\begin{array}{c}\text { IA-24A } \\
\text { chk }\end{array}$ & $\begin{array}{c}\text { IA-20A } \\
\text { chk }\end{array}$ & $\begin{array}{c}\text { IA-11 } \\
\text { glg }\end{array}$ & $\begin{array}{c}\text { IA-20 } \\
\text { glg }\end{array}$ \\
\hline $\mathrm{SiO}_{2}$ & 62.28 & 64.24 & 65.71 & 66.20 & 72.67 & 70.64 & 74.02 & 75.16 & 77.59 \\
\hline $\mathrm{TiO}_{2}$ & 1.32 & 0.99 & 1.00 & 0.94 & 0.34 & 0.45 & 0.27 & 0.22 & 0.16 \\
\hline $\mathrm{Al}_{2} \mathrm{O}_{3}$ & 15.14 & 14.64 & 14.56 & 14.54 & 13.48 & 13.52 & 12.74 & 12.18 & 11.88 \\
\hline $\mathrm{Fe}_{2} \mathrm{O}_{3}$ & 6.66 & 5.43 & 5.26 & 4.85 & 2.35 & 3.87 & 2.37 & 2.14 & 1.45 \\
\hline $\mathrm{MnO}$ & 0.11 & 0.11 & 0.10 & 0.09 & 0.04 & 0.06 & 0.04 & 0.04 & 0.03 \\
\hline $\mathrm{MgO}$ & 1.52 & 1.11 & 1.10 & 0.98 & 0.36 & 0.37 & 0.21 & 0.15 & 0.12 \\
\hline $\mathrm{CaO}$ & 3.71 & 2.87 & 2.51 & 2.33 & 1.14 & 1.63 & 1.04 & 0.78 & 0.63 \\
\hline $\mathrm{Na}_{2} \mathrm{O}$ & 3.75 & 3.33 & 4.06 & 4.02 & 3.13 & 3.23 & 2.64 & 2.64 & 2.82 \\
\hline $\mathrm{K}_{2} \mathrm{O}$ & 4.43 & 4.85 & 4.98 & 5.10 & 5.35 & 5.68 & 5.86 & 5.80 & 5.27 \\
\hline $\mathrm{P}_{2} \mathrm{O}_{5}$ & 0.46 & 0.34 & 0.29 & 0.27 & 0.09 & 0.07 & 0.03 & 0.02 & 0.01 \\
\hline LOI & 0.44 & 0.87 & 0.40 & 0.22 & 0.78 & 0.10 & 0.37 & 0.36 & 0.28 \\
\hline Total & 99.82 & 98.78 & 99.97 & 99.53 & 99.72 & 99.62 & 99.59 & 99.49 & 100.24 \\
\hline $\mathrm{Ba}$ & 1618 & 1385 & 1380 & 1435 & 567 & 819 & 602 & 386 & 82 \\
\hline $\mathrm{Ce}$ & 163 & 181 & 160 & 104 & 116 & 232 & 269 & 305 & 103 \\
\hline $\mathrm{Cl}$ & 179 & 128 & 297 & 223 & 59 & $<50$ & $<50$ & $<50$ & $<50$ \\
\hline $\mathrm{Co}$ & 14 & 8 & 9 & 6 & $<6$ & $<6$ & $<6$ & $<6$ & $<6$ \\
\hline $\mathrm{Cr}$ & $<13$ & $<13$ & $<13$ & $<13$ & $<13$ & $<13$ & $<13$ & $<13$ & $<13$ \\
\hline $\mathrm{Cu}$ & 9 & $<5$ & $<5$ & $<5$ & $<5$ & $<5$ & $<5$ & 7 & $<5$ \\
\hline $\mathrm{F}$ & 2445 & 2239 & 2035 & 1838 & $<550$ & 564 & 564 & $<550$ & 569 \\
\hline $\mathrm{Ga}$ & 23 & 22 & 22 & 21 & 21 & 19 & 18 & 17 & 18 \\
\hline $\mathrm{La}$ & 110 & 136 & 114 & 59 & 90 & 185 & 219 & 252 & 83 \\
\hline $\mathrm{Nb}$ & 39 & 43 & 46 & 44 & 10 & 14 & $<9$ & $<9$ & 10 \\
\hline $\mathrm{Nd}$ & 106 & 88 & 88 & 47 & 62 & 113 & 133 & 153 & 60 \\
\hline $\mathrm{Ni}$ & 7 & $<5$ & $<5$ & $<5$ & $<5$ & $<5$ & $<5$ & $<5$ & $<5$ \\
\hline $\mathrm{Pb}$ & 22 & 24 & 24 & 21 & 34 & 16 & 18 & 19 & 26 \\
\hline $\mathrm{Rb}$ & 149 & 180 & 152 & 156 & 179 & 164 & 161 & 157 & 202 \\
\hline $\mathrm{S}$ & $<300$ & $<300$ & $<300$ & $<300$ & $<300$ & $<300$ & $<300$ & $<300$ & $<300$ \\
\hline $\mathrm{Sc}$ & 16 & 14 & 15 & $<14$ & $<14$ & $<14$ & $<14$ & $<14$ & $<14$ \\
\hline $\mathrm{Sr}$ & 413 & 315 & 311 & 319 & 118 & 81 & 58 & 35 & 13 \\
\hline Th & 13 & 24 & 26 & 32 & 30 & 51 & 45 & 40 & 79 \\
\hline $\mathrm{U}$ & $<3$ & 4 & 6 & 8 & 13 & 11 & 13 & 15 & 16 \\
\hline $\mathrm{V}$ & 81 & 58 & 51 & 40 & 12 & 20 & 20 & $<9$ & $<9$ \\
\hline Y & 66 & 69 & 65 & 58 & 33 & 53 & 46 & 40 & 34 \\
\hline $\mathrm{Zn}$ & 103 & 99 & 97 & 88 & 50 & 60 & 56 & 51 & 39 \\
\hline $\mathrm{Zr}$ & 655 & 553 & 704 & 637 & 276 & 520 & 400 & 280 & 161 \\
\hline mg\# & 31.3 & 28.9 & 29.4 & 28.7 & 23.4 & 16.0 & 14.1 & 12.3 & 14.2 \\
\hline $\mathrm{A} / \mathrm{CNK}$ & 0.85 & 0.92 & 0.88 & 0.89 & 1.04 & 0.94 & 1.01 & 1.01 & 1.03 \\
\hline $\mathrm{N} / \mathrm{K}$ & 1.29 & 1.04 & 1.24 & 1.20 & 0.89 & 0.86 & 0.68 & 0.69 & 0.81 \\
\hline $\mathrm{Ba} / \mathrm{Sr}$ & 3.9 & 4.4 & 4.4 & 4.5 & 4.8 & 10.1 & 10.1 & 11.0 & 6.3 \\
\hline Zrsat & 875 & 877 & 895 & 888 & 869 & 886 & 876 & 842 & 796 \\
\hline
\end{tabular}

Zrsat = zircon saturation temperatures, in degrees Celsius; mg\# = molecular $\mathrm{MgO} /(\mathrm{MgO}+\mathrm{FeO}($ total $)) ; \mathrm{A} / \mathrm{CNK}=$ molecular $\mathrm{Al}_{2} \mathrm{O}_{3} /\left(\mathrm{CaO}+\mathrm{Na}_{2} \mathrm{O}+\mathrm{K}_{2} \mathrm{O}\right) ; \mathrm{N} / \mathrm{K}=$ molecular $\mathrm{Na}_{2} \mathrm{O} / \mathrm{K}_{2} \mathrm{O}$. 

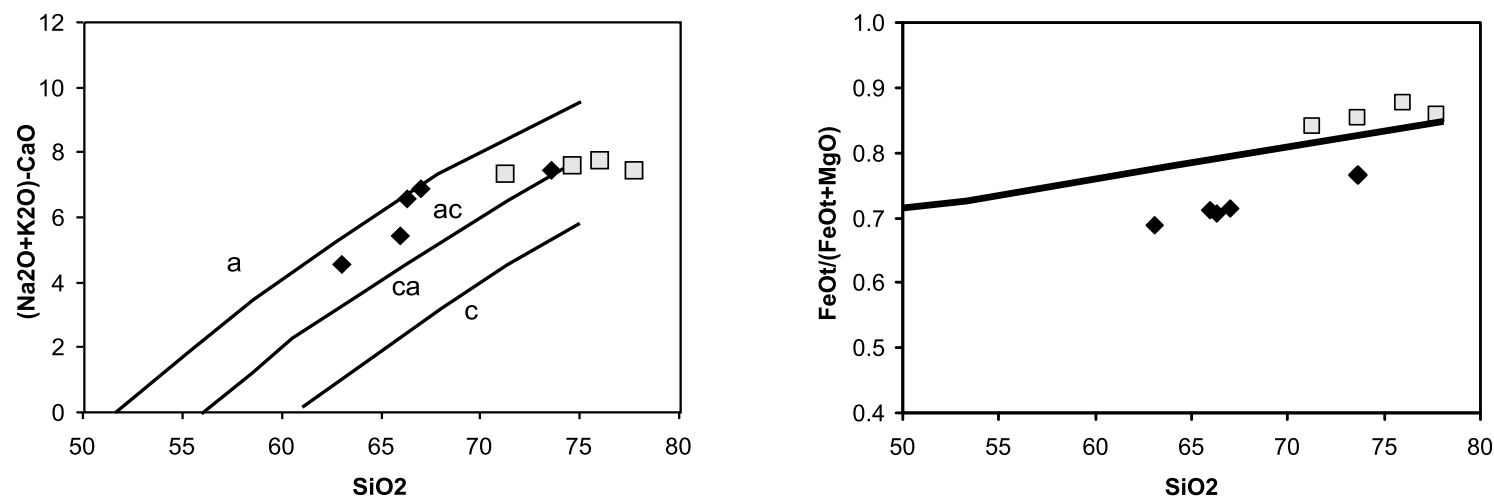

Fig. 6 - Geochemical parameters (Frost et al. 2001) for classification of the IAQM and enclosing charnockitic-granitic rocks: (a) $\left(\mathrm{Na}_{2} \mathrm{O}+\mathrm{K}_{2} \mathrm{O}\right)-\mathrm{CaO} \times \mathrm{SiO}_{2}$ diagram; (b) $(\mathrm{FeOt}+\mathrm{MgO}) /(\mathrm{FeOt})$ diagram.
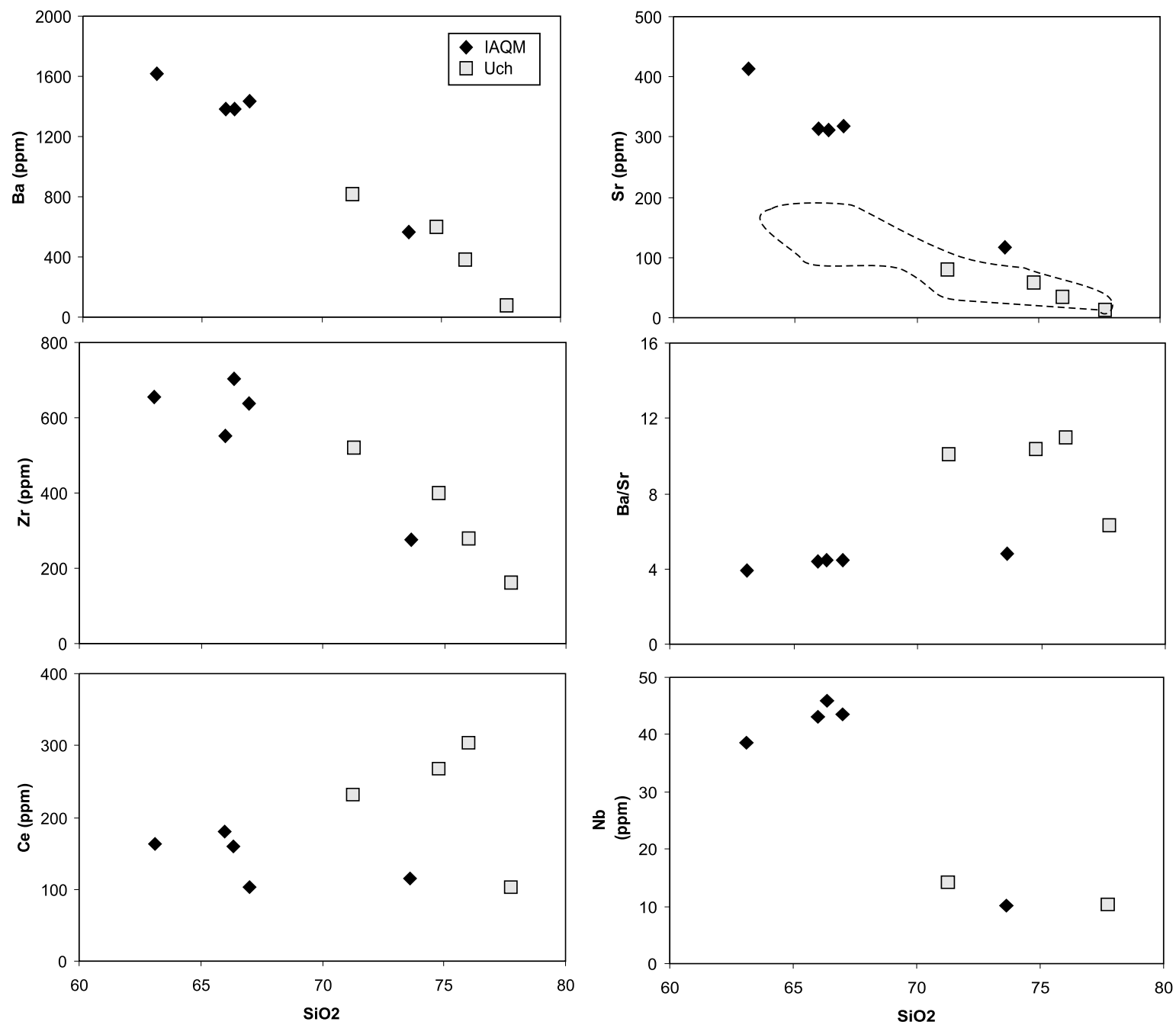

Fig. 7 - Major and minor element variation diagrams using $\mathrm{SiO}_{2}$ as a differentiation index for IAQM and enclosing charnockiticgranitic rocks. 

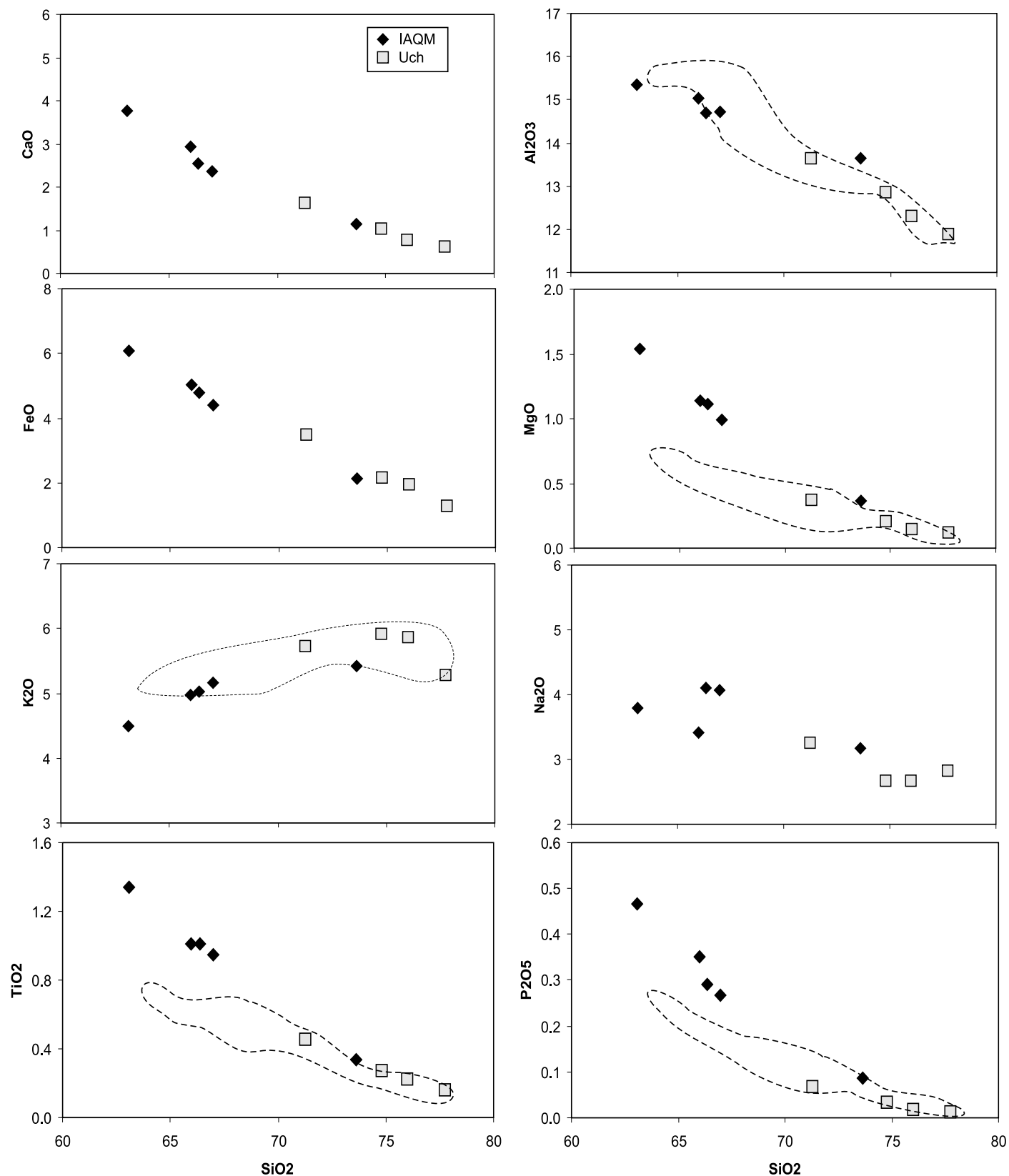

Fig. 8 - Trace-element variation diagrams using $\mathrm{SiO}_{2}$ as a differentiation index for IAQM and enclosing charnockiticgranitic rocks.

tents, 35-80 ppm). High contents of HFSE as $\mathrm{Nb}(\sim 40$ ppm) and $\mathrm{Zr}(550-700 \mathrm{ppm})$ are typical of the IAQM; this is also a feature of the least fractionated samples from the UCB. The Zr contents are suggestive of relatively high temperature magmas in both cases; zircon saturation temperatures calculated from the formulation of Watson and Harrison (1983) are $895-875^{\circ} \mathrm{C}$ for the IA quartz monzonites, and $885-875^{\circ} \mathrm{C}$ for the UB charnockites (Table I).

\section{CONCLUSIONS}

This paper presents the first study devoted to the Ilha Anchieta Quartz Monzonite, which was known in the literature from a brief description in a regional mapping report (A.T.S.F. Silva et al. 1977, unpublished report). Field relationships demonstrate that the pluton is intrusive into foliated felsic charnockites and associated leucogranites that are part of the Ubatuba Charnockite 
Batholith, thus far the youngest granitic rock dated in the state of São Paulo ( $565 \mathrm{Ma}$; Gasparini and Mantovani 1979, C. Tassinari, personal communication). LA-MCICPMS U-Pb zircon dating has shown that the IAQM is indeed very young (499.7 $\pm 5.9 \mathrm{Ma})$, and can be interpreted as an extension of the "G5" belt of late-Brasiliano alkali-calcic granites and associated high-K mafic rocks described by Pedrosa-Soares et al. (2001) and Wiedemann et al. (2002).

A border facies with trachytoid structure present at the western contact of the IAQM is slightly more felsic (CI 8-11) than samples of typical porphyritic quartz monzonite from the inner portions of the pluton. The latter appear to be at least in part cumulative, as evidenced by outcrop-scale structures, such as steep inward-dipping modal and grain-size layering. Recharge of the chamber by basic magmas is evidenced by elliptical mafic microgranular enclaves with textures indicative of interaction with the host granite; in one local, a larger ( $\sim 2$ meter-thick) body of fine-grained mafic rock appears to have split up as concordant layers within the quartz monzonite. Differentiated granites are restricted, at the exposed portion of the pluton, to metersized intrusive pods found in several outcrops and to thin aplite dikes.

The IAQM chemical signature appears to be similar to those of coeval "G5" occurrences such as the Santa Angélica and Várzea Alegre plutons in Espírito Santo (Wiedemann et al. 2002), combining high HFSE contents (especially $\mathrm{Nb}$ and $\mathrm{Zr}$ ) with some geochemical features that are not typical of within-plate granites, such as an alkali-calcic and magnesian character, as well as the relatively high contents of LILE (e.g., K, Ba, $\mathrm{Sr}$ ), LREE and $\mathrm{P}_{2} \mathrm{O}_{5}$ shown by associated basic rocks. These features have been attributed to the involvement of distinct sources in the enriched mantle and a metaluminous lower crust (Ludka et al. 1998, Campos et al. 2004). The renewed influx of mantle-derived magmas in a post-collisional setting at 510-500 Ma appears to be connected with cessation of convergence and slab break off (Wiedemann et al. 2002, Campos et al. 2004).

The older Ubatuba Charnockite Batholith has a chemical signature that is clearly distinct from the IAQM, with major and trace-element signatures typical of within-plate, "A-type" granites (e.g., syenogranitic composition; low mg\# and $\mathrm{Sr}$; high $\mathrm{Zr}$, Nb). However, these rocks are affected by a solid-state foliation, and their $\sim 565 \mathrm{Ma}$ age is identical to "syn-collisional" granites elsewhere in the Oriental Terrane (Heilbron and Machado 2003, Campos et al. 2004, Heilbron et al. 2008). The significance of this high-temperature magmatism (anhydrous, with liquidus $\mathrm{T}$ up to $900^{\circ} \mathrm{C}$ ) associated with mantle-derived mafic bodies has yet to be fully understood, since it is by no means typical of a "syn-collisional" environment and could imply a period of extensional tectonics preceding the last compressional events recorded in the Oriental Terrane at 530-510 Ma (Heilbron et al. 2008).

\section{ACKNOWLEDGMENTS}

Rafael Fernando Honório and Márcia Helena Galina are thanked for drawing the geological map. Financial support for this project was provided by Fundação de Amparo à Pesquisa do Estado de São Paulo (FAPESP) (Proc. 07/00635-5) and Instituto Geológico, Secretaria do Meio Ambiente do Estado de São Paulo (Proc. SMA 30.132/2006). We thank the Instituto Florestal - Diretoria do Parque Estadual da Ilha Anchieta - PEIA, for giving support to our field work. The Radiogenic Isotope Facility at the University of Alberta is partially supported by NSERC Discovery and Major Resources Support Grants to LMH.

\section{RESUMO}

O Quartzo Monzonito Ilha Anchieta (QMIA) ocupa a maior parte da ilha homônima na região costeira do Estado de São Paulo, e é intrusivo em rochas foliadas do Charnockito Ubatuba ( $\sim 565 \mathrm{Ma})$. A principal variedade petrográfica é um biotitahornblenda quartzo monzonito porfirítico com foliação magmática e megacristais tabulares de microclínio com 2-4 cm em matriz de granulação média. Estruturas em afloramento indicam processos cumuláticos (bandamento modal e granulométrico) e interação com magmas básicos (enclaves microgranulares máficos). Dados geoquímicos indicam que a variedade principal é intermediária a ácida $\left(\mathrm{SiO}_{2}=63-67 \%\right)$, tem caráter álcali-cálcico, metaluminoso e magnesiano ( $\mathbf{m g \# ~} 30)$, conteúdos moderados de $\mathrm{Sr}(300-400$ ppm) e Ba ( 1500 ppm) e conteúdos relativamente altos de $\operatorname{HFSE}(\mathrm{Nb}=40 \mathrm{ppm} ; \mathrm{Zr}$ $=550-700 \mathrm{ppm})$. Os charnockitos encaixantes mais antigos são mais félsicos $\left(\mathrm{SiO}_{2}=71-78 \%\right)$, ferrosos $(\mathbf{m g \#}=12-16)$, e têm teores muito baixos de $\mathrm{Sr}$ (13-80 ppm), resultando em razões $\mathrm{Ba} / \mathrm{Sr}$ notavelmente mais altas que o QMIA (10 versus 
4). Datação de zircão do QMIA por LA-MC-ICPMS indicou $499.7 \pm 5.9 \mathrm{Ma}$, a idade magmática mais jovem identificada até o momento no embasamento cristalino do Estado de São Paulo, e indica que o plúton marca a extensão meridional do magmatismo pós-colisional tardio ("G5") do Cinturão Ribeira.

Palavras-chave: granito, litogeoquímica, LA-ICPMS, datação U-Pb de zircão, Cinturão Ribeira.

\section{REFERENCES}

Alves A. 2009. Petrogênese de plútons graníticos do leste paulista: geocronologia, geoquímica elemental e isotópica. Doctoral Thesis, Instituto de Geociências, Universidade de São Paulo, São Paulo, Brasil, 122 p.

Brito Neves BB, Campos Neto MC and Fuck RA. 1999. From Rodinia to Western Gondwana: An approach to the Brasiliano-Pan African Cycle and orogenic collage. Episodes 22(3): 155-166.

Campos C, Mendes JC, LudKa I, Medeiros SM, MouRA JC AND Wallfass C. 2004. A review of the Brasiliano magmatism in southern Espírito Santo, Brazil, with emphasis on post-collisional magmatism. Journal of the Virtual Explorer, 17 (http://virtualexplorer.com.au/article/ 2004/106/brasiliano-magmatism/index.html).

Campos Neto MC. 2000. Orogenic systems from Southwestern Gondwana: An approach to Brasiliano-PanAfrican cycle and orogenic collage in Southeastern Brazil. In: CORDANi UG, MiLANi EJ, ThOMAZ FILHO A AND CAmpos DA (Eds), Tectonic Evolution of South America. $31^{\text {st }}$ International Geological Congress, Rio de Janeiro, p. $355-365$.

Campos Neto MC and Figueiredo MCH. 1995. The Rio Doce orogeny, southeastern Brazil. J South Amer Earth Sci 8(2): 143-162.

Dias Neto CM, Correia CT, Munhá JMU And TAssiNARI CCG. 2008. Litoquímica dos granitóides da estrutura em flor de São Sebastião, São Paulo. Geologia USP, Ser Cient 8(2): 101-114.

Frost BR, Barnes CG, Collins WJ, Arculus RJ, ELLIS DJ AND Frost CD. 2001. A geochemical classification for granitic rocks. J Petrol 42(11): 2033-2048.

GARDA GM. 1996. Os piroxênios dos diques máficos e ultramáficos do litoral entre São Sebastião e Ubatuba, SP. Geochim Brasil 10(2): 297-323.

GASPARINi P AND Mantovani MSM. 1979. Geochemistry of charnockites from São Paulo State, Brazil. Earth Planet Sci Lett 42(2): 311-320.
Heilbron M And Machado N. 2003. Timing of terrane accretion in the Neoproterozoic-Eopaleozoic Ribeira orogen (SE Brazil). Precambrian Res 125(1-2): 87-112.

Heilbron M, VAleriano CM, TAssinari CCG, AlmeiDA J, Tupinambá M, Siga JR O AND Trouw R. 2008. Correlation of Neoproterozoic terranes between the Ribeira Belt, SE Brazil and its African counterpart: comparative tectonic evolution and open questions. Geol Soc London Spec Publ 294(1): 211-237.

JANASi VA, Alves A AND Vlach SRF. 2003. Granitos peraluminosos da porção central da Faixa Ribeira, Estado de São Paulo: sucessivos eventos de reciclagem da crosta continental no neoproterozóico. Geologia USP, Ser Cient 3: $13-24$.

LUDKA IP, WIEDEMANN CM AND TÖPFNER C. 1998. On the origin of incompatible element enrichment in the Venda Nova Pluton, State of Espírito Santo, southeast Brazil. J South Amer Earth Sci 11(5): 473-486.

Mori Pe, Reeves S, Correia CT and HaukKa M. 1999. Development of a fused glass disc XRF facility and comparison with the pressed powder pellet technique at Instituto de Geociências, Universidade de São Paulo. Rev Bras Geoc 29: 441-446.

Pedrosa-Soares AC, Noce CM, Wiedemann CM ANd PInTo CP. 2001. The Araçuaí-West-Congo Orogen in Brazil: an overview of a confined orogen formed during Gondwanaland assembly. Precambrian Res 110(1-4): 307-323.

SCHMitT RS, TROUW RAJ, VAN Schmus WR AND PIMENTEL MM. 2004. Late amalgamation in the central part of West Gondwana: new geochronological data and the characterization of a Cambrian collisional orogeny in the Ribeira Belt (SE Brazil). Precambrian Res 133(1-2): $29-61$.

Silva LC, McNaughton NJ, Armstrong R, HartMANN LA AND FLETCHER IR. 2005. The neoproterozoic Mantiqueira Province and its African connections: a zircon-based $\mathrm{U}-\mathrm{Pb}$ geochronologic subdivision for the Brasiliano/Pan-African systems of orogens. Precambrian Res 136(3-4): 203-240.

Simonetti A, Heaman LM And Chacko T. 2008. Use of discrete-dynode secondary electron multipliers with Faradays - A 'reduced volume' approach for in-situ U-Pb dating of accessory minerals within petrographic thin section by LA-MC-ICP-MS, Sylvester P (Ed), V.M. Goldschmidt Laser Ablation Short Course 40: 241-264.

Simonetti A, Heaman LM, Hartlaub RP, Creaser RA, MCHATTIE TG AND BÖHM C. 2005. U-Pb dating 
of zircon by laser ablation-MC-ICP-MS using a new multiple ion counting-faraday collectory array. J Anal Atom Spectr 20: 677-686.

STERN RA AND AMELIN Y. 2003. Assessment of errors in SIMS zircon $\mathrm{U}-\mathrm{Pb}$ geochronology using a natural zircon standard and NIST SRM 610 glass. Chem Geol 197: 111-142.

Streckeisen A. 1976. To each plutonic rock its proper name. Earth-Sci Rev 12(1): 1-33.

TupinambÁ M, Teixeira W And Heilbron M. 2000. Neoproterozoic Western Gondwana assembly and subduction-related plutonism: the role of the Rio $\mathrm{Ne}$ gro Complex in the Ribeira Belt. Rev Bras Geoc 30(1): 7-11.
Valente SC, Corval A, Duarte BP, Ellam RM, Fallick AE, Meighan IG AND Dutra T. 2007. Tectonic boundaries, crustal weakness zones and plumesubcontinental lithospheric mantle interactions in the Serra do Mar dyke swarm, SE Brazil. Rev Bras Geoc 37(1): 194-201.

WATSON EB AND HARRISON TM. 1983. Zircon saturation revisited: temperature and composition effects in a variety of crustal magma types. Earth Planet Sci Lett 64(2): 295-304.

Wiedemann CM, Medeiros SR, LudKa IP, Mendes JC And Costa-De-Moura J. 2002. Architecture of Late Orogenic Plutons in the Aracuai-Ribeira Fold Belt, Southeast Brazil. Gondwana Res 5(2): 381-399. 